\title{
Original article \\ Concurrent training effect on muscle fibers in Wistar rats
}

\author{
Robson Chacon Castoldi \\ Regina Celi Trindade Camargo \\ Alan José Barbosa Magalhães \\ Guilherme Akio Tamura Ozaki \\ Fábio Yoshikazu Kodama \\ Sérgio Minoru Oikawa \\ Marcelo Papoti \\ José Carlos Silva Camargo Filho \\ São Paulo State University at Presidente Prudente, Brazil
}

\begin{abstract}
The aim of the present study was to determine the modeling of muscle fibers in rats submitted to different exercise protocols. Fifty-five Wistar rats were submitted divided into four different groups: Control group ( $\mathrm{CG} ; \mathrm{N}=16$ ); endurance training group (ETG; $\mathrm{N}=13$ ), strength training group ( $\mathrm{STG} ; \mathrm{N}=13$ ) and concurrent training group (CTG; N=13). The intensity of endurance training was determined by the critical workload. Statistical analysis involved the Kruskal-Wallis test for multiple comparisons, followed by Dunn's post test $(p<0.05)$. All animals submitted to training exhibited an increase in the cross-sectional area of the muscle fibers. The largest increase $(p>0.05)$ occurred in the STG and CTG at both four (mean:2952,95 $\pm 878,39$ mean:2988,84 \pm 822,58) and eight weeks respectively (mean:3020,26 \pm 800.91; mean:3104,91 $\pm 817,87$ ). The findings demonstrate similar results obtained with strength training and concurrent training, with a greater increase in muscle fiber area in both groups in comparison to the control group and group submitted to endurance training.
\end{abstract}

Keywords: skeletal muscle, soleus muscle, concurrent training, aerobic exercise, anaerobic exercise

Resumo- "Efeito do treinamento concorrente nas fibras musculares de ratos Wistar." O objetivo deste estudo foi observar a modelação das fibras musculares de ratos submetidos a diferentes protocolos de treinamento físico. Foram utilizados 55 animais da raça Wistar, dos quais foram submetidos a quatro diferentes tratamentos, sendo estes: o grupo controle (CTLE), treinamento aeróbio (TAE), treinamento de força (TAN) e treinamento concorrente (TCc). A intensidade do treinamento aeróbio foi determinada pela carga crítica de trabalho. Utilizouse o teste de Kruscal-Wallis para comparações múltiplas, com pós-teste de Dunn, adotou-se o valor de significância de $5 \%(p=0,05)$. Observou-se que os grupos de animais treinados mostraram aumento na área de secção transversa (AST) das fibras musculares. Não foi verificada diferença significante $(p>0,05)$ entre os grupos TAN e TCc, tanto em quatro (média:2952,95 \pm 878,39 média:2988,84 \pm 822,58) como após oito semanas (média:3020,26 \pm 800,91; média:3104,91 \pm 817,87). Os protocolos de TAN e TCc não se diferenciaram entre si e demonstraram aumento da AST quando comparados aos demais grupos de animais.

Palavras-chaves: músculo esquelético, músculo sóleo, treinamento concorrente, exercício anaeróbico

Resumen- "Efecto del entrenamiento concurrente en fibras musculares de las ratas Wistar." Nota el modelado de las fibras musculares en ratas sometidas a diferentes protocolos del entrenamiento físico. Se utilizaron 55 ratas Wistar, que fueron sometidas a cuatro tratamientos diferentes: grupo de control (CTLE), entrenamiento aeróbico (TAE), entrenamiento de fuerza (TF) y la entrenamiento concurrente (TC). La intensidad de entrenamiento aeróbico se determinó por el carga crítica del trabajo. Se utilizó la prueba Kruscal-Wallis para comparaciones múltiples con Dunn del postest, se adoptó el nivel del significancia en 5\% $(p=0,05)$. Se observó que lós grupos de animales entrenados mostraron una mayor área de sección transversal (AST) en las fibras musculares. No hubo diferencia significativa $(p>0,05)$ entre el TF y TC, tanto en cuatro (media:2952,95 \pm 878,39; media:2988,84 \pm 822,58) y después de ocho semanas (media:3020,26 \pm 800,91; media:3104,91 \pm 817,87). Se concluyó que los protocolos de TF y TC no difirieron. Además, demostraron aumento del AST en comparación con los otros grupos de animales.

Palabras claves: músculo esquelético, músculo sóleo, entrenamiento concurrente, ejercicio aeróbico, ejercicio anaeróbico 


\section{Introduction}

Physical exercise leads to a series of adaptations in skeletal muscle, including changes in the structures of the muscle cells (sarcoplasm) and cell metabolism (Hood, Irrcher, Ljubicic, \& Joseph, 2003; Little, Safdar, Wilkin, Tarnopolsky, \& Gibala, 2010). Due to its plasticity, skeletal muscle undergoes changes in its microscopic components (actin and myosin), which become thicker, resulting in an increase in contraction force. This process is denominated hypertrophy. Moreover, nuclei and mitochondria undergo changes in both size and number (Yeo, Paton, Garnham, Burke, Carey, \& Hawley, 2008).

Aerobic endurance training leads to enhanced blood circulation in the peripheral vessels, whereas strength training leads to an increase in the myofilaments actin and myosin, enhancing muscle contraction force (Jambassi Filho, Gurjão, Gonçalves, Barboza, \& Gobbi, 2010; Teixeira, Ritti-Dias, Tinucci, Mion Júnior, \& Forjaz, 2011). Thus, researchers have proposed a method of training that employs both these forms of exercise, denominated "concurrent training."

Robert C. Hickson (1980) was the first author to describe this procedure and a number of investigations into the effects of this form of training have since been conducted. Reviews of the literature carried out by Leveritt, Abernethy, Barry, and Logan (1999), and Paulo, Souza, Laurentino, Ugrinowitsch, and Tricoli (2005) reported that some authors state that the combination of the two training methods in a single session may have a considerable structural and metabolic impact on muscle fibers, resulting in the loss of contractile force and physical capacity (Hickson, 1980). According to Baar (2006), however, little was known in the 1980 s regarding the effects concurrent training on physical fitness, the increase in muscle mass and mitochondrial density. Thus, a number of authors began to state that such effects may not occur or may be related to gender, physical state and the balance between the volume and intensity employed in the training protocol (Docherty, \& Sporer, 2000; Sale, Jacobs, MacDougall, \& Garner, 1990).

The advantages of concurrent training include the possibility of developing two distinct physical capacities in a single session and an increase in energy expenditure, which can be used to combat excess body weight and obesity. However, there are gaps in the knowledge and a lack of clarity regarding the actual effect of this form of physical training. Likewise, few studies have investigated microscopic units in skeletal muscles following concurrent training. Thus, the aim of the present study was to determine the modeling of muscle fibers in rats submitted to different exercise protocols (endurance training, strength training and concurrent training).

\section{Methods}

\section{Animals}

Fifty-five adult male Wistar rats (aged 90 days) were acquired from the animal lodging facility of the São Paulo State University (UNESP), Botucatu Campus (Brazil), and maintained in the lodging facility for small rodents of the Physical Therapy Department of the same university (Presidente Prudente campus). The animals were kept five per cage (polyethylene) at a controlled temperature (22 \pm $2^{\circ} \mathrm{C}$ ) and 12-hour light/dark cycle with free access to food (standard laboratory chow) and water.

This study received approval from the Animal Research Ethics Committee of the UNESP School of Science and Technology (Presidente Prudente campus) under protocol number 002/2011 and was conducted in compliance with the norms and ethical principles governing animal experimentation.

\section{Experimental groups}

The animals were divided into four different groups: Control group ( $\mathrm{CG} ; \mathrm{N}=16)$; endurance training group (ETG; $N=13$ ), strength training group (STG; $N=13$ ) and concurrent training group ( $\mathrm{CTG} ; \mathrm{N}=13$ ). A baseline group (BL) was determined at the time of the initial experiment. For the analysis of the four week period, 22 animals were euthanized for data acquisition, and 23 animals were used for the data analysis of the eight week period.

All animals, except those in the control group, were submitted to an adaptation period to the liquid medium and equipment 10 to $20 \mathrm{~min} /$ day five days a week for three weeks, with progressive increases in load and duration, as proposed by Manchado, Gobatto, Contarteze, Papoti, and Mello (2006). An adaptation period reduces the stress caused by the liquid medium and physiological changes resulting from physical training (Chimin, Araújo, Manchado-Gobatto, \& Gobatto, 2009).

\section{Acquisition of tissue samples}

For the analysis of the four week period, 22 animals were euthanized for the acquisition of soleus muscle tissues ( 5 in the CG, 6 in the ETG, 6 in the STG and 5 in the CTG). Twenty-three animals were used for the analysis of the eight week period (6 in the CG, 7 in the ETG, 7 in the STG and 5 in the CTG). At the time of the initial experiment BL group included 5 animals selected from the CTLE group. However, three animals were lost (1 in the first four weeks and 2 in the last four weeks), resulting in a final sample of 20 animals that was used for the analysis of the eight-week period.

\section{Physical training protocols}

CG: The animals remained in their cages with free access to food and water.

ETG: Endurance training consisted of a 30-minute swimming session three days a week in appropriate tanks subdivided by PVC cylinders allowing each animal to train individually. The load was defined based on the blood lactate 
test and the weight was attached to the posterior region of the thorax using a specifically designed bag for use in this training model.

STG: Strength training was composed of a four sets of 10 jumps three days a week in a cylindrical PVC recipient specially modified for jumping in water at an appropriate depth based on the length of the animal. A one-minute rest interval (determined using a chronometer) was given between sets. The load corresponded to $50 \%$ of the body weight of each animal, with a $10 \%$ increase after four weeks of training. The weight was attached to the anterior region of the thorax using a vest, as proposed by De Mello Malheiro, Giacomini, Justulin, Delella, Dall-Pai-Silva, and Felisbino (2009).

CTG: Concurrent training was the combination of the two aforementioned protocols, one of which was predominantly aerobic (swimming) and one was predominantly anaerobic (jumps). Aerobic exercise (30 minutes of swimming) was performed first, with the load stipulated by the determination of the anaerobic threshold based on the critical workload, followed by anaerobic exercise (4 sets of 10 jumps), with a load of $50 \%$ of the body weight of each animal.

\section{Determination of critical workload and anaerobic threshold}

The critical workload (CWL) and aerobic capacity (AeC) were determined through exercise induction with four different stimuli. Four different loads corresponding to $7,9,11$ and $13 \%$ of body weight were used and the exercise was performed such that the animal would reach exhaustion between two and 10 minutes (Hill, 1993). The time limit (Tlim) for the performance of the exercise at each load was determined with the aid of a chronometer. The animals remained at rest for 48 hours between each stimulus. This procedure was adapted from the method proposed by Marangon, Gobato, Mello, and Kokobun (2002) and reproduced by Chimin et al. (2009). The values established for the two variables were obtained from the following formula: critical load $=\mathrm{CWL}+($ AeC $\times 1 /$ Tlim $)$. The animals were then trained with a load corresponding to $70 \%$ of the anaerobic threshold.

\section{Euthanasia}

Forty-eight hours after the last exercise session, the animals were submitted to the surgical procedure at different pre-established times (Table 1). The samples were obtained using the methods described by Águila, Apfel, and Mandarim-De-Lacerda, (1997). Thirty minutes prior to euthanasia, an intraperitoneal injection of heparin $(25,000$ IU) was administered and the animals were anesthetized with an intraperitoneal injection of a combination of ketamine and xylazine (40 mg/kg of body weight), as proposed by Seraphim, Nunes, and Machado, (2001). Perfusion of the left ventricle was performed with $1 \mathrm{ml}$ of $\mathrm{KCl} 10 \%$ until diastolic cardiac arrest. The soleus muscle was then collected from all animals.

\section{Histological processing of soleus muscle}

The muscle tissue was immersed in n-hexane cooled in liquid nitrogen using the freezing method for non-fixed tissues and stored at $-80^{\circ} \mathrm{C}$. Cuts measuring $5 \mu \mathrm{m}$ in thickness were made on a cryostat microtome at $-20^{\circ} \mathrm{C}$, placed on slides and stained with hematoxylin-eosin for the analysis of the structure of the muscles.

\section{Analysis of muscle tissues}

Cuts submitted to staining and histochemical reactions were examined under normal and polarized light and photomicrographed in a Nikon ${ }^{\circledR}$ microscope (model H550S). The Infinity 1 camera was used for the image analysis. Interactive marking for the determination of the mean cross-sectional area was performed using the Auxio VisionRel 4.8 (Carl Zeiss $^{\circledR}$ ) and NIS-Elements D3.0 - SP7

Table 1. Experiment time protocol.

\begin{tabular}{|c|c|c|c|c|c|c|c|c|}
\hline & \multicolumn{8}{|c|}{ Weeks of training } \\
\hline & 1 & 2 & 3 & 4 & 5 & 6 & 7 & 8 \\
\hline \multirow[t]{2}{*}{ Control } & E1 & & & $\mathrm{E}$, & & & & $\mathrm{E}$, \\
\hline & $\mathrm{CC}$ & & & $\mathrm{CC}$ & & & & $\mathrm{CC}$ \\
\hline \multirow{3}{*}{ Endurance training } & $\mathrm{X}$ & $\mathrm{X}$ & $\mathrm{X}$ & $\mathrm{X}$ & $\mathrm{X}$ & $\mathrm{X}$ & $\mathrm{X}$ & $\mathrm{X}$ \\
\hline & $\mathrm{CC}$ & & & $\mathrm{E}$, & & & & $\mathrm{E}$, \\
\hline & & & & $\mathrm{CC}$ & & & & $\mathrm{CC}$ \\
\hline \multirow[t]{3}{*}{ Strength training } & $\mathrm{X}$ & $\mathrm{X}$ & $\mathrm{X}$ & $\mathrm{X}$ & $\mathrm{X}$ & $\mathrm{X}$ & $\mathrm{X}$ & $\mathrm{X}$ \\
\hline & $\mathrm{CC}$ & & & $\mathrm{E}$, & & & & $\mathrm{E}$, \\
\hline & & & & $\mathrm{CC}$ & & & & $\mathrm{CC}$ \\
\hline \multirow[t]{3}{*}{ Concurrent training } & $\mathrm{X}$ & $\mathrm{X}$ & $\mathrm{X}$ & $\mathrm{X}$ & $\mathrm{X}$ & $\mathrm{X}$ & $\mathrm{X}$ & $\mathrm{X}$ \\
\hline & $\mathrm{CC}$ & & & $\mathrm{E}$, & & & & $\mathrm{E}$, \\
\hline & & & & $\mathrm{CC}$ & & & & $\mathrm{CC}$ \\
\hline
\end{tabular}

Legend: $\mathrm{X}=$ physical training; $\mathrm{E}=$ euthanasia and muscle tissue collection; $\mathrm{E} 1$ = initial euthanasia for determination of baseline; $\mathrm{CC}=$ critical workload and aerobic capacity evaluation. 
(Nikon ${ }^{\circledR}$ ) programs. One hundred muscle fibers were examined on each slide, following the protocol established by Dal Pai Silva (1995).

\section{Statistical analysis}

The data were tested for normality using the ShapiroWilk test. As non-normal distribution was demonstrated, the Kruskal-Wallis was employed, followed by Dunn's post test for the in between groups analysis and Wilcoxon test for the analysis of the protocol after four and eight weeks, with the level of significance set to $5 \%(p<0.05)$. All calculations were performed using the SPSS 17.0 for Windows ${ }^{\circledR}$.

\section{Results}

The analysis of the tissue samples revealed that the animals in the STG and CTG exhibited greater hypertrophy of the muscle fibers at both the four-week and eight-week evaluations (Figures 1 and 2).

In the intra-group analysis, an increase in crosssectional area of the fibers was found in all four groups at both the four-week and eight-week evaluations (Figure 3).

In the inter-group analysis at the four-week evaluation, the mean muscle fiber area was similar in the STG and CTG, with significantly higher values in comparison to the other groups (Figure 4).

In the inter-group analysis at the eight-week evaluation, the mean muscle fiber area was once again similar in the STG and CTG, with significantly higher values in comparison to the other groups (Figure 5).

\section{Discussion}

This study investigated the effects of concurrent physical training on the soleus muscle in Wistar rats over

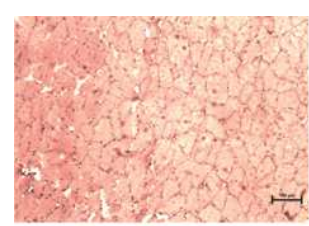

A

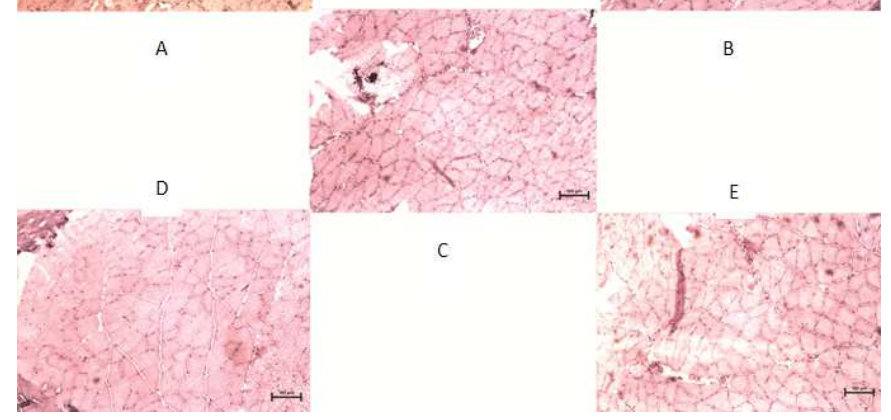

Figure 1. Soleus muscle fibers after four weeks in different groups; Legend: A - baseline; B - control; C - endurance training; D - strength training; E - concurrent training; Scale bar $=100$ micrometers.

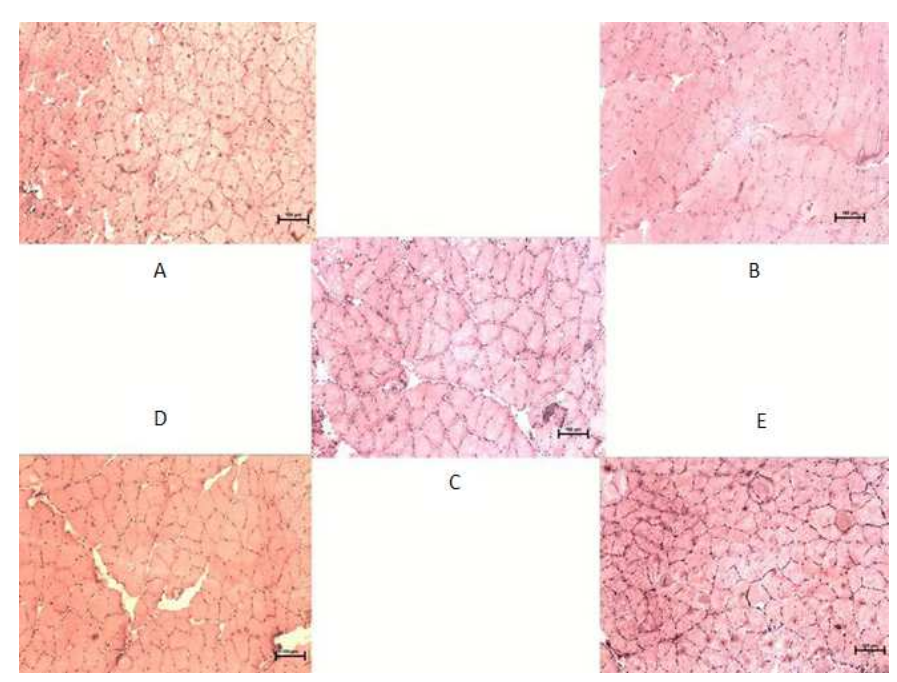

Figure 2. Soleus muscle fibers after eight weeks in different groups; Legend: A - baseline; B - control; C - endurance training; D - strength training; E - concurrent training; Scale bar $=100$ micrometers.

an eight-week period. No significant differences were found between the results of concurrent training and strength training alone. Moreover, both groups (CTG and STG) exhibited more accentuated hypertrophy in comparison to the other groups (CG and ETG).

The two protocols selected for the present study have been previously tested in the literature - endurance training (swimming) and strength training (jumping exercise in water). The critical workload established by Chimin et al. (2009) and jump training proposed by De Malheiro et al. (2009) were used for the measurement of aerobic capacity. An increase in the cross-sectional area of the muscle fibers was found in all groups at both the four-week and eightweek evaluation. This finding demonstrates that, although adult animals were used, maturational development occurred throughout the study. However, the increase in the groups having undergone training was more accentuated than that in the control group at both four and eight weeks. Moreover, the increase in muscle fiber area was greater in both the STG and CTG in comparison to the ETG $(p>0.05)$. Studies have shown that endurance training is a useful means of enhancing cardiopulmonary capacity, leading to peripheral vasodilatation of the blood vessels, a reduction in both heart rate and systemic blood pressure and an increase in the size and number of mitochondria in skeletal muscle (Hood et al., 2006, Lovato, Anunciação, \& Polito, 2012). Moreover, enhanced aerobic capacity offers additional benefits, such as an increase in total volume during the sessions, including the strength component (Dias et al., 2006). However, despite the increase in the area of the muscle fibers, the animals in the ETG exhibited a lesser degree of hypertrophy in comparison to the STG and CTG. Moreover, the lack of a statistically significant difference between the STG and CTG regarding the occurrence of hypertrophy suggests that concomitant training did not lead to a reduction in physical capacity. 

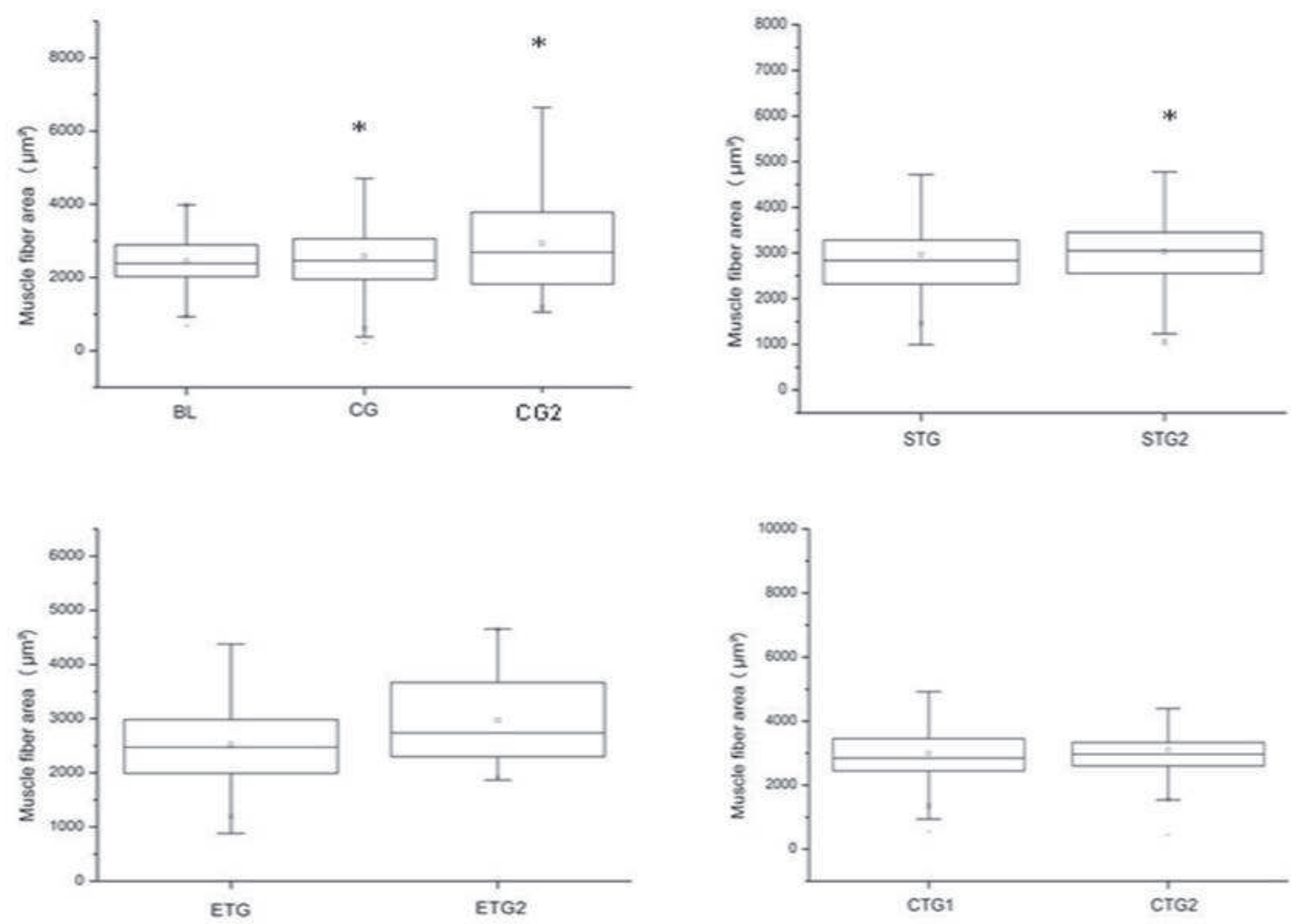

Figure 3. Cross-sectional area of muscle fibers pre and post-training in each group. (BL): Baseline group; (CG - CG2): Control group; (STG - STG2): Strength training group; (ETG - ETG2): Endurance training group; (CTG - CTG2): Concurrent training group. After four and eight weeks respectively. $(*)$ : Wilcoxon test $(p<0.05)$.

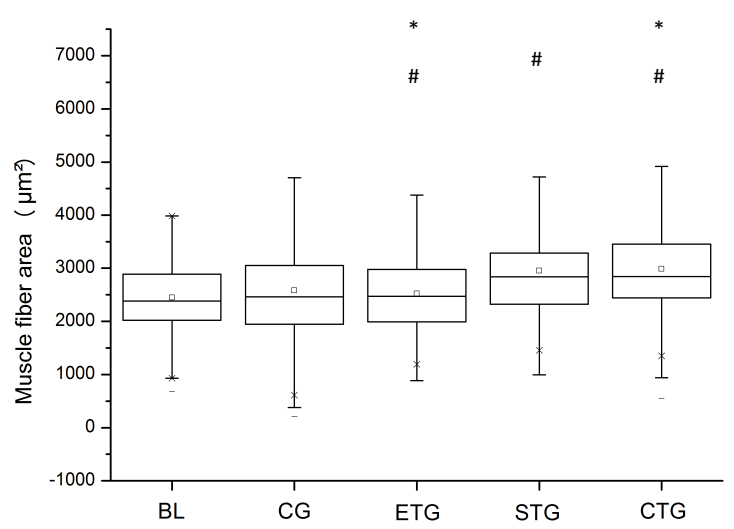

Figure 4. Mean area of muscle fibers in different groups at fourweek evaluation; (\#) Significant difference in comparison to BL and CG; (*) Significant difference in comparison to ETG. (BL): Baseline group; (CG): Control group; (ETG): Endurance training group; (STG): Strength training group; (CTG): Concurrent training group.

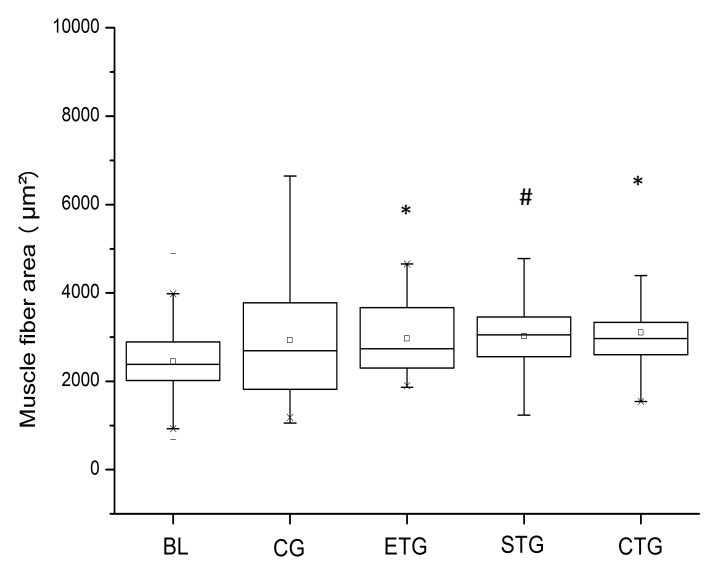

Figure 5. Mean area of muscle fibers in different groups at eightweek evaluation; (\#) Significant difference in comparison to baseline and CG; (*) Significant difference in comparison to ETG; (BL): Baseline group; (CG): Control group; (ETG): Endurance training group; (STG): Strength training group; (CTG): Concurrent training group. 
The present findings demonstrate that concurrent training performed three times a week did not have a negative impact on the adaptation of skeletal muscle tissue, despite the different stimuli caused by the distinct forms of physical exercise (aerobic endurance and muscle strength). In a review carried out by Loveritt et al. (1999), all findings demonstrating an increase in muscle strength were achieved using a protocol with three weekly sessions, as performed in the present study. Moreover, McCarthy, Agre, Graf, Pozniak, and Vailas (1995) found that concurrent training performed three times a week for a ten-week period led to an increase in vertical jumps and knee extension and found similar gains when these activities were performed at frequencies of three and five days a week.

Bell, Syrotuik, Martin, Burnham, and Quinney (1997) analyzed 45 male and female individuals and found an increase in the area of type I and type II fibers after six and 12 weeks in the group submitted to strength training alone, whereas an increase was only found in type II fibers after 12 weeks in the group submitted to concurrent training. The authors concluded that the findings support the hypothesis that the combination of strength and aerobic resistance training may suppress some of the adaptations to strength training and increase the capillarization of skeletal muscle.

Leveritt, Abernethy, Barry, and Logan (2003) found an improvement in $1 \mathrm{MR}$ strength in both the strength training and concurrent training groups. Moreover, a significant increase in $\mathrm{VO}_{2 \max }$ was found in the endurance training and concurrent training groups. The authors also state that the power of the statistical tests and the selection of dependent variables are important factors to improving knowledge on concurrent training and that it may be necessary to evaluate a variety of performance parameters to determine the efficacy of this training method.

The present findings lend support to the hypothesis of the non-interference of concurrent training on skeletal muscle and are in disagreement with the presupposition that this form of training exerts a negative influence of the development of physical capacity. According to Nader (2006), for many years, a series of mechanisms was proposed for the limitation to the adaptation of skeletal muscle, contributing toward the inhibition of strength developed during concurrent training. However, a number of studies suggest that concurrent training may lead to a state of over-training and a consequent reduction in physical capacity. Hennessy and Watson (1994) found a decrease in limb strength in rugby players who performed aerobic resistance and strength training simultaneously over an eight-week period.

Kraemer et al. (1995) found a reduction in $1 \mathrm{MR}$ strength among 35 male soldiers following 12 weeks of concurrent training. However, the increase in $\mathrm{VO}_{2 \max }$ was similar to that in the group submitted to strength training alone. In contrast, no significant difference was found between the animals submitted to strength training and concurrent training in the present study.
The present findings demonstrate that the concurrent physical training protocol was effective in causing hypertrophy in the skeletal muscles of Wistar rats. However, this study was restricted to determining the effect of this procedure using a swimming protocol. Studies involving a treadmill, vertical climbing or electrostimulation may complement the findings shown in the present study.

\section{Conclusion}

Both strength training and concurrent training were effective in increasing the cross-sectional area of muscle fibers. Moreover, no significant difference was found between these two forms of training.

\section{References}

Águila, M.B., Apfel, M.I.R., \& Mandarim-De-Lacerda, C.A. (1997). Comparação Morfológica e Bioquímica entre Ratos Envelhecidos Alimentados com Dieta Hiperlipídica e com Óleo de Canola. Arquivos Brasileiros de Cardiologia, 68, 155-161.

Baar, K. Training for endurance and strength: lessons from cell signaling. (2006). Medicine Science in Sports and Exercise, 38, 1939-1944.

Bell, G. J., Syrotuik, D., Martin, T. P., Burnham, R., \& Quinney, H. A. (1997). Effect of strength training and concurrent strength and endurance training on strength, testosterone, and cortisol. Journal of Strength and Conditioning Research, 11, 57-64.

Chimin, P., Araújo, G.G., Manchado-Gobatto, F.B., \& Gobatto, C. A.. (2009). Critical load during continuous and discontinuous training in swimming Wistar rats. Motricidade Fundação Técnica e Científica do Desporto, 5, 45-58.

Dal Pai Silva, M. (1995). Histoenzimologia: teoria e prática. Instituto de Biociências - Unesp, Botucatu.

De Mello Malheiro, O. C., Giacomini, C. T., Justulin, L. A. Jr., Delella, F. K., Dall-Pai-Silva,M., Felisbino, S. L. (2009). Calcaneal tendon regions exhibit different mmp-2 activation after vertical jumping and Treadmill Running. The Anatomical Record, 292, 1656-62. doi: 10.1002/ar.20953

Dias, R., Prestes, J., Manzatto, R., Ferreira, C. K. O., Donatto, F. F., Foschini, D., \& Cavaglieri, C. R. (2006). Efeitos de diferentes programas de exercício nos quadros clínico e funcional de mulheres com excesso de peso. Revista Brasileira de Cineantropometria e Desempenho Humano, 8, 58-65.

Docherty, D., Sporer, B. (2000). A Proposed Model for Examining the Interference Phenomenon between Concurrent Aerobic and Strength Training. Sports Medicine, 30, 385-394.

Hennessy, L. C., \& Watson, A. W. S. (1994). The interference effects of training for strength and endurance simultaneously. Journal of Strength and Conditioning Research, 8, 12-9.

Hickson, R.C. (1980). Interference of strength development by simultaneously training for strength and endurance. European Journal of Applied Physiology, 45, 255-263. doi: 10.1007/ BF00421333

Hill, D. W. (1993). The critical power concept. Sports Medicine, $16,237-254$

Hood, D. A., Irrcher, I., Ljubicic, V., \& Joseph, A. M. (2003). Coordination of metabolic plasticity in skeletal muscle. The Journal of Experimental Biology, 209, 2265-2275. doi: $10.1242 /$ jeb.02182

Jambassi Filho, J. C., Gurjão, A. L. D., Gonçalves, R., Barboza, B. 
H. V., \& Gobbi, S. (2010). O Efeito de diferentes intervalos de recuperação entre as séries de treinamento com pesos, na força muscular em mulheres idosas treinadas. Revista Brasileira de Medicina do Esporte, 16, 122-115. doi:org/10.1590/S151786922010000200007

Kraemer, W. J., Patton, J. F., Gordon, S. E., Harman, E. A., Deschenes, M. R., Reynolds, K., . . \& \& Dziados, J. E. (1995). Compatibility of high-intensity strength and endurance training on hormonal and skeletal muscle adaptations. Journal of Applied Physiology, 78, 976-89.

Leveritt, M., Abernethy, P. J., Barry, B. K., \& Logan, P. A. (1999). Concurrent Strength and Endurance Training: A Review. Sports Medicine, 28, 413-427.

Leveritt, M., Abernethy, P. J., Barry, B., \& Logan, P. A. (2003). Concurrent strength and endurance training: the influence of dependent variable selection. The Journal of Strength and Conditioning Research, 17, 503-508. doi: 10.1519/15334287(2003)017

Little J. P., Safdar, A., Wilkin, G. P., Tarnopolsky, M. A., \& Gibala, M. J. (2010). A practical model of low-volume high-intensity interval training induces mitochondrial biogenesis in human skeletal muscle: potential mechanisms. The Journal of Physiology 588, 1011-1022. doi: 10.1113/jphysiol.2009.181743

Lovato, N. S., Anunciação, P. G., \& Polito, M. D. (2012). Pressão arterial e variabilidade de frequência cardíaca após o exercício aeróbio e com pesos realizados na mesma sessão. Revista Brasileira de Medicina do Esporte, 18, 817-826. doi: 10.1016/ S0028-3932(01)00178-6

Manchado, F. B., Gobatto, C. A., Contarteze, R. V. L., Papoti, M., \& Mello, M.A.R. (2006). Máxima fase estável de lactato é ergômetro-dependente em modelo experimental utilizando ratos. Revista Brasileira de Medicina do Esporte,12, 259-262. doi.org/10.1590/S1517-86922006000500007

Marangon, L., Gobato, C. A., Mello, M. A. R., \& Kokobun, E. (2002). Utilization of an hyperbolic model for the determination of critical load in swimming rats. Applied Physiology, Nutrition and Metabolism, 34, (suppl.), 149.

McCarthy, J. P., Agre, J. C., Graf, B. K., Pozniak, M. A., \& Vailas, A. C. (1995). Compatibility of adaptive responses with combining strength and endurance training. Medicine and Science in Sports and Exercise, 27, 429-36.

Nader, G. A. (2006). Concurrent strength and endurance training: from molecules to man. Medicine Science in Sports and Exercise, 38, 1965-70. doi: 10.1249/01.mss.0000233795. 39282.33

Paulo, A. C., Souza, E. O., Laurentino, G., Ugrinowitsch, C., \& Tricoli, V. (2005). Efeito do treinamento concorrente no desenvolvimento da força motora e da resistência aeróbia. Revista Mackenzie de Educação Física e Esporte, 4, 145154.

Sale, D. G., Jacobs, I., MacDougall, J. D., \& Garner, S. (1990). Comparison of two regimens of concurrent strength and endurance training. Medicine and Science in Sports and Exercise, 22, 348-56.

Seraphim, P.M., Nunes, M.T., \& Machado, U.F. (2001). GLUT4 protein expression in obese and lean 12-month-old rats: insights from different types of data analysis. Brazilian Journal Médicine Biology Research, 34, 1353-1362. doi:org/10.1590/ S0100-879X2001001000018

Teixeira, L., Ritti-Dias, R. M., Tinucci, T., Mion Júnior, D., \& Forjaz, C. L. (2011). Post-concurrent exercise hemodynamics and cardiac autonomic modulation. European Journal of Applied Physiology, 111, 2069-2078. doi: 10.1007/s00421-010-1811-1
Yeo, W. K., Paton, C. D., Garnham, A. P., Burke, L. M., Carey, A. L., \& Hawley, J. A. (2008). Skeletal muscle adaptation and performance responses to once a day versus twice every second day endurance training regimens. Journal of Applied Physiology, 105, 1462-1470. doi:10.1113/jphysiol.2009.181743

\section{Authors' note}

Robson Chacon Castoldi (http://lattes.cnpq.br/3219816625135266) is with the Physical Therapy Department, São Paulo State University (UNESP), Presidente Prudente/SP, Brazil, and with the Physical Education Department. The University of Western São Paulo (UNOESTE), Presidente Prudente/SP, Brazil.

Regina Celi Trindade Camargo (http://lattes.cnpq.br/68080807 52084158), Alan José Barbosa Magalhães (http://lattes.cnpq.br/3101398370218033), Guilherme Akio Tamura Ozaki (http://lattes. cnpq.br/4218579396180443), Fábio Yoshikazu Kodama (http://lattes.cnpq.br/5535293994707529) and José Carlos Silva Camargo Filho (http://lattes.cnpq.br/74072546945 14123) are with the Physical Therapy Department. São Paulo State University (UNESP), Presidente Prudente/SP, Brazil.

Sérgio Minoru Oikawa (http://lattes.cnpq.br/4182935185298861) is with the Department of Mathematics, Statistics and Computation. São Paulo State University (UNESP), Presidente Prudente/SP, Brazil.

Marcelo Papoti (http://lattes.cnpq.br/3559493742302365) is with the Physical Education Department. São Paulo State University (UNESP), Presidente Prudente/SP, Brazil, and with the São Paulo University. Physical Education School and Sport of Ribeirão Preto.

\section{Acknowledgments}

The authors are grateful to the Brazilian Agency of Resources for Higher Education Personnel (CAPES) and to the Physical Therapy Department and Graduate Program in Physical Therapy for supporting the development of this study.

\section{Correspondence to:}

Robson Chacon Castoldi

Rua Roberto Simonsen, 305, Bairro Centro Educacional

19060-900 Pres. Prudente, SP, Brazil

Phone: (55-18) 3229-5388

Fax: (55-18) 3221-4391

Manuscript received on December 17, 2012

Manuscript accepted on August 18, 2013

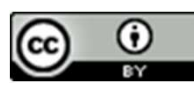

Motriz. Journal of Physical Education. UNESP, Rio Claro, SP, Brazil, eISSN: 1980-6574, is licenced under a Creative Commons License, Version 3.0. 